\title{
Recovery trajectories during state change from bare sediment to eelgrass dominance
}

\author{
Karen J. McGlathery ${ }^{1, *}$, Laura K. Reynolds ${ }^{1}$, Luke W. Cole ${ }^{1}$, Robert J. Orth ${ }^{2}$, \\ Scott R. Marion ${ }^{2}$, Arthur Schwarzschild ${ }^{1}$ \\ ${ }^{1}$ Department of Environmental Sciences, University of Virginia, PO Box 400123, Charlottesville, Virginia 22903, USA \\ ${ }^{2}$ Virginia Institute of Marine Science, School of Marine Science, 1208 Greate Road, College of William and Mary, \\ Gloucester Point, Virginia 23062, USA
}

\begin{abstract}
Seagrasses are important foundation species in shallow coastal ecosystems that provide critical ecosystem services including stabilizing sediment, sequestering carbon and nutrients, and providing habitat and an energy source for a diverse fauna. We followed the recovery of functional (primary productivity, carbon and nitrogen sequestration, sediment deposition) and structural (shoot density, biomass, plant morphometrics) attributes of Zostera marina (eelgrass) meadows in replicate large plots ( 0.2 to $0.4 \mathrm{ha}$ ) restored by seeding in successive years, resulting in a chronosequence of sites from 0 (unvegetated) to $9 \mathrm{yr}$ since seeding. Shoot density was the structural metric that changed most significantly, with an initial $4 \mathrm{yr}$ lag, and a rapid, linear increase in plots 6 to $9 \mathrm{yr}$ after seeding. Changes in $Z$. marina aerial productivity, sediment organic content, and exchangeable ammonium showed a similar trend with an initial 4 yr lag period before differences were observed from initial bare sediment conditions. After $9 \mathrm{yr}, Z$. marina meadows had $20 \times$ higher rates of areal productivity than 1 to $3 \mathrm{yr}$ old meadows, double the organic matter and exchangeable ammonium concentrations, $3 \times$ more carbon and $4 \times$ more nitrogen, and had accumulated and retained finer particles than bare, unvegetated sediments. These results demonstrate the reinstatement of key ecosystem services with successful large-scale restoration, although none of the parameters reached an asymptote after $9 \mathrm{yr}$, indicating that at least a decade is required for these attributes to be fully restored, even in an area with high habitat suitability. Survivorship along a depth gradient showed that $\sim 1.6 \mathrm{~m}$ (mean sea level) is the maximum depth limit for $Z$. marina, which matches the 'tipping point' for survival predicted for this system from a non-linear hydrodynamic/seagrass growth model.
\end{abstract}

KEY WORDS: Eelgrass · Zostera marina · Restoration · Seagrass · Coastal bays · Ecosystem services

\section{INTRODUCTION}

Seagrasses are recognized as important foundation species in shallow coastal ecosystems that both modify the physical habitat and modulate ecosystem processes. The complex structure of seagrasses compared to unvegetated sediments enhances biodiversity (Duffy 2006) and alters local hydrodynamics by attenuating wave energy and currents, which influences sediment suspension and deposition (Ward et al. 1984, Fonseca \& Fisher 1986, Gacia et al. 2002,
Folkard 2005, Gruber \& Kemp 2010, Hansen \& Reidenbach 2012, this Theme Section). Seagrass habitats also sequester carbon (C) and nutrients, support higher trophic levels, and provide energy and biomass subsidies to other marine ecosystems (Duarte et al. 2005, 2010, Heck et al. 2008, Kennedy et al. 2010). Long-term trends in seagrass abundance and distribution indicate that the rate of habitat loss due to degraded water quality, disturbance, and disease is accelerating worldwide and is accompanied by a loss of the services that these ecosystems provide (Orth et 
al. 2006a, Waycott et al. 2009, Short et al. 2011). Modeling of future climate scenarios suggests that seagrass habitats are also vulnerable to an increase in storm frequency and temperature, and that synergistic effects between water quality and climate change could further accelerate seagrass decline (Carr et al. 2010, Carr et al. 2012, this Theme Section). Small changes in environmental factors (light, temperature, nutrients, disturbance) may lead to a rapid and catastrophic loss of seagrass, and a shift to a bare, unvegetated state (van der Heide et al. 2007, Carr et al. 2010). Although there have been some successes in large-scale restoration efforts to mitigate these losses, these have not been enough to reverse the declining trends globally (Orth et al. 2006a).

Restoration efforts have the greatest probability of success if habitat suitability is high (i.e. the habitat has not been degraded or degradation has been reversed), and if donor material is from comparable conditions and has high genetic diversity (Short et al. 2002, van der Heide et al. 2007, van Katwijk et al. 2009, Fonseca 2011, Reynolds et al. 2012, this Theme Section). The most important habitat characteristics influencing restoration success are water column light attenuation, sediment characteristics (e.g. porewater redox, sulfide, organic content, grain size), and local hydrodynamics (Koch 2001, Short et al. 2002, van der Heide et al. 2007, van Katwijk et al. 2009). The existence of alternative states of clear water/seagrass conditions and turbid water/no seagrass in shallow ecosystems occurs primarily because of the positive feedback of seagrasses on dampening sediment suspension and improving water clarity (van der Heide et al. 2007, Carr et al. 2010). Recent studies have suggested that this feedback also should be incorporated into guidelines for restoration (van Katwijk et al. 2009).

Which metrics are best used to judge restoration success is a matter of some debate (Palmer et al. 1997, Fonseca et al. 1998, Short et al. 2002), but include structural and/or functional attributes of the system. Generally, structural aspects for seagrass ecosystems include shoot density, plant morphometrics, and biomass as proxies for habitat structure (Fonseca et al. 1996a, 1998, Evans \& Short 2005, Leschen et al. 2010, Li et al. 2010). Functional aspects are typically measures of primary productivity, faunal abundance and community composition, and sediment trapping (Fonseca et al. 1996b, 1998, Evans \& Short 2005, Leschen et al. 2010). Metrics in restored habitats are generally compared with natural, reference meadows, although the selection of suitable reference sites by which to judge appropriate restoration endpoints can be problematic, especially in degraded habitats or in areas where seagrass loss is widespread. Assessment of functional trajectories describing the development of ecological functions over time can be used to assess when functional equivalency is reached in seagrass restoration projects (Craft et al. 2003, Evans \& Short 2005, Bell et al. 2008). Our study is the first to monitor long-term (9 yr) trajectories of recovery in seagrass meadows following restoration by seeding.

The local extinction of Zostera marina in the Virginia, USA, coastal bay region in the early 1930s due to disease and storm disturbance is a striking example of the loss of ecosystem services with seagrass habitat loss (Orth et al. 2006b, Orth \& McGlathery 2012 , this Theme Section). The extirpation of $Z$. marina led to an immediate decline of commercially and recreationally important species, including bay scallops Argopecten irradians and brant Branta bernicla (Milne \& Milne 1951, Orth et al. 2006b). Following the loss of the sediment-stabilizing service of $Z$. marina, it was debated whether the continued absence of $Z$. marina was the result of light or seed limitation. Recent studies have indicated that much of the seafloor in the coastal bays is suitable habitat for $Z$. marina recolonization based on light attenuation (Lawson et al. 2007) and that the lack of recovery was likely due to seed limitation (Orth et al. 2012, this Theme Section). The discovery of a small patch of $Z$. marina in the late 1990s spurred a large-scale effort to restore $Z$. marina that has resulted in approximately 1700 ha of $Z$. marina habitat from an original 125 ha seeded throughout the Virginia coastal bays as of 2012 (Orth et al. 2006b, 2012). Here we describe the recovery trajectories of both functional and structural attributes of $Z$. marina meadows restored by seeding in successive years, resulting in a chronosequence of sites from 0 (unvegetated) to $9 \mathrm{yr}$ since seeding. We follow the terminology of Elliot et al. (2007) where 'restoration' refers to 're-creating habitat that was present within historical records.' We measured plant and sediment parameters that quantify the reinstatement of key ecosystem services, i.e. primary productivity, $\mathrm{C}$ and nutrient sequestration, and sediment deposition, with successful large-scale restoration initiated by seeding.

\section{MATERIALS AND METHODS}

\section{Site description}

The seed additions were done within the Virginia Coast Reserve Long Term Ecological Research (VCR 
LTER) site on the eastern shore of Virginia. The coastal bay system is bound to the west by the Delmarva Peninsula and to the east by barrier islands; exchange with Atlantic Ocean waters is through narrow inlets between the islands. Water residence times are spatially variable, averaging $16 \mathrm{~d}$, and ranging from $30 \mathrm{~d}$ near the mainland margin to 2 tidal cycles near the inlets (Fugate et al. 2006). The coastal bays are shallow, with $50 \%<1$ m at mean low water (Oertel 2001), and have a tidal range of 1.2 to $1.3 \mathrm{~m}$ (Table 1). Watershed nitrogen $(\mathrm{N})$ loading to the coastal bays averages $2.1 \mathrm{~g} \mathrm{~N} \mathrm{~m}^{-2} \mathrm{yr}^{-1}$ (Cole 2011) and is extremely low compared to similar shallow coastal bays in the US and other countries (McGlathery et al. 2007). As a result, water quality (based on dissolved nutrients, chlorophyll) is high and has shown no negative trends for the last 2 decades (VCR LTER data base, www1.vcrlter.virginia.edu/home1/ ?q=data_wq). The high water quality and availability of long-term data on primary productivity and nutrient cycling (e.g. McGlathery et al. 2001, Tyler et al. 2001, 2003, Anderson et al. 2003, 2010) make this an ideal location to understand the consequences of state change from an algal- to a seagrass-dominated system. The seed plots were located at $\left(37^{\circ} 24^{\prime} 47^{\prime \prime} \mathrm{N}\right.$,

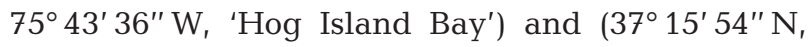
$75^{\circ} 48^{\prime} 50^{\prime \prime} \mathrm{W}$, 'South Bay') within the coastal bay system and were separated by mudflats and a tidal

Table 1. Comparison of hydrodynamic, sediment, and water column characteristics of eelgrass restoration sites in Hog Island Bay (HIB) and South

Bay (SB) in the Virginia coastal bay system, USA. MSL: mean sea level

\begin{tabular}{|c|c|c|}
\hline & HIB & SB \\
\hline Depth (MSL, m) & $0.9-1.6$ & $0.9-1.6$ \\
\hline \multicolumn{3}{|l|}{ Water column ${ }^{\mathrm{a}}$} \\
\hline Median annual turbidity (NTU) & $5.2-11.4$ & $7.8-16.9$ \\
\hline Median annual chlorophyll $\left(\mu g \mathrm{l}^{-1}\right)$ & $4.8-7.0$ & $3.8-6.9$ \\
\hline \multicolumn{3}{|l|}{ Hydrodynamics $^{b}$} \\
\hline \multicolumn{2}{|l|}{ Current } & 1.32 \\
\hline Tidally-averaged mean $\left(\mathrm{cm} \mathrm{s}^{-1}\right)$ & $1.3-3.5$ & $3.5-4.4$ \\
\hline Maximum $\left(\mathrm{cm} \mathrm{s}^{-1}\right)$ & $7.1-18.0$ & $13.2-18.0$ \\
\hline \multicolumn{3}{|l|}{ Sediment } \\
\hline$\%$ organic matter & $1.68 \pm 0.23$ & $1.17 \pm 0.19$ \\
\hline$\% \mathrm{~N}$ & $0.01 \pm 0.005$ & $0.008 \pm 0.001$ \\
\hline$\% \mathrm{C}$ & $0.35 \pm 0.06$ & $0.33 \pm 0.05$ \\
\hline$\%$ sand $(63-250 \mu \mathrm{m})$ & $80.19 \pm 4.39$ & $84.36 \pm 5.47$ \\
\hline$\%$ silt/clay $(<63 \mu \mathrm{m})$ & $19.81 \pm 4.29$ & $15.64 \pm 5.47$ \\
\hline $\begin{array}{l}\text { Exchangeable } \mathrm{NH}_{4}^{+}(\mu \mathrm{mol} \mathrm{N} \\
\mathrm{g}^{-1} \text { dry wt of sediment) }\end{array}$ & $0.0239 \pm 0.003$ & $0.0236 \pm 0.002$ \\
\hline \multicolumn{3}{|c|}{$\begin{array}{l}\text { a Data from Orth et al. (2012) } \\
{ }^{b} \text { Data calculated from coastal ocean circulation model, FVCOM (Chen } \\
\text { et al. 2006), run for } 5 \text { tidal cycles to reach steady-state conditions }\end{array}$} \\
\hline
\end{tabular}

channel. The sites are comparable with respect to bathymetry and water depth, sediment and water column characteristics in unvegetated regions (representing initial conditions), and current speeds (Table 1). Both have light penetration capable of supporting Zostera marina production (Lawson et al. 2007, Orth et al. 2012).

\section{Experimental design}

Plots were seeded in 2001, 2006, 2007, and 2008, and Zostera marina and sediment parameters (see below) were measured annually mid-summer in 2007 to 2010 , which resulted in a gradient in $Z$. marina colonization from 1 to $9 \mathrm{yr}$. Meadows seeded in South Bay in 2001 were sampled 6 to 9 yr after seeding; meadows seeded in Hog Island Bay in 2006 to 2008 were sampled 1 to $4 \mathrm{yr}$ after seeding. Vegetated sites were compared with nearby 'bare' unvegetated plots ( $\mathrm{n}=12,6$ at each site), which represented the initial condition (0 yr time point; Table 1$)$. Seeds were harvested by hand from stable $Z$. marina populations in nearby Chesapeake Bay and subsequently from the expanding meadow in South Bay in the $\mathrm{VCR}_{\text {; }}$ full details of the collection and seeding methodology can be found in Orth et al. (2012). Briefly, reproductive shoots with mature seeds were collected in late spring and were held in flowing outdoor seawater tanks; released seeds were separated from detritus and were kept in seawater until they were distributed by hand broadcasting in the fall just prior to the normal period of seed germination in this region (Moore et al. 1993). In total, 4.4 million seeds were added to the plots included in the present study, and 37.9 million seeds throughout all of the coastal bays (Orth et al. 2012). Establishment rates for seeds broadcast in the fall and assessed as seedlings the following spring in these coastal bays were 2 to $7 \%$ (Orth et al. 2012).

Seeds were broadcast in 2001 and 2008 into 0.4 ha plots at densities of 100000 seeds $0.4 \mathrm{ha}^{-1}$; we followed 6 plots seeded in 2001 and 6 plots seeded in 2008. The plots seeded in 2006 to 2008 were located along a depth gradient from 0.9 to $1.6 \mathrm{~m}$ at mean sea level (MSL). In 2006 and 2007, seeds were broadcast in a $2 \times 2$ factorial design to compare plot size $(0.2$ and $0.4 \mathrm{ha}$ ) and seed density (50000 and 
100000 seeds $0.4 \mathrm{ha}^{-1}$ ), with 7 plots treatment ${ }^{-1}$ in 2006 and 6 plots treatment ${ }^{-1}$ in 2007 . The uneven plot replication between years was due to variation in the number of seeds available in a given year. Analyses of sediment and plant parameters showed no significant effects of plot size or seed density in either 2006 or 2007, and so all plots were pooled for each of these years for comparisons of the different aged plots. Here we refer to 'age' as time since seeding. This resulted in sample sizes from 6 to 28 plots for a given age. Within each plot, 3 to 10 replicate samples were analyzed for specific plant and sediment parameters (detailed below), so individual plot replication incorporated the variation within a plot. Replicate samples were collected along transects extending $50 \mathrm{~m}$ in 0.4 ha plots and $25 \mathrm{~m}$ in 0.2 ha plots through the center of each plot. Samples were collected equidistant along the transect line depending on the number of replicates.

\section{Eelgrass metrics}

In each plot, Zostera marina shoot density was determined by counting individual shoots in situ in 10 quadrats (0.25 $\mathrm{m}^{2}$ each). Quadrats were placed at a random distance perpendicular to the transect line at each sampling point. For biomass estimates, 3 cores (15.24 cm inner diameter) containing shoots were collected, including sediment and eelgrass biomass to $20 \mathrm{~cm}$ depth, in each plot. The cores were sieved in situ to remove sediments. In the laboratory, shoots were separated into aboveground and belowground biomass for each core, and the number of shoots was counted to obtain estimates of total, above-, and belowground biomass per shoot. To separate biomass into above- and belowground portions, we cut the shoots at the root primordia, where the presence of 2 small bumps at the base of the shoot indicated the formation of a new rhizome internode. Canopy height was determined in the laboratory as the average height of the 3 tallest leaves. Pooled samples of leaf tissue and rhizome/root tissue for each core were dried at $60^{\circ} \mathrm{C}$ to a constant weight and ground to a fine powder using a Digital Wig-LBug ${ }^{\circledR}$ Mixer/Amalgamator. C and N contents were determined on 3 to $7 \mathrm{mg}$ samples for plant tissue and 20 to $30 \mathrm{mg}$ samples for sediments using a Carlo Erba Elemental Analyzer with a $1020^{\circ} \mathrm{C}$ combustion tube and $650^{\circ} \mathrm{C}$ reduction tube, and helium as a carrier gas.

In 4 plots for each age class, plant productivity was measured on all shoots within a $20 \times 10 \mathrm{~cm}$ anchored grid using the leaf-marking method, where the blades were punctured with a 22-gauge needle using the top of the sheath bundle as the reference point. Shoots were collected 10 to $15 \mathrm{~d}$ after marking, and leaf area and dry weights of the older growth (above the scar) and the new growth (below the scar, but excluding the sheath bundle and including new shoots) were measured.

\section{Sediment metrics}

Sediments were collected in $60 \mathrm{~cm}^{3}$ syringe corers in each vegetated and bare plot for determination of sediment organic content, $\mathrm{C}$ and $\mathrm{N}$ contents, exchangeable ammonium, and grain size distribution. We standardized our sampling to collect the top $5 \mathrm{~cm}$ where we expected to see meadow effects on these sediment parameters independent of the accumulation of belowground biomass. Five cores were collected in each plot for each analysis; the reported values represent the integrated measure for the 0 to $5 \mathrm{~cm}$ depth interval. Sediment organic content was calculated as loss on ignition from sediment dry weight after combustion in a $500^{\circ} \mathrm{C}$ muffle furnace for $8 \mathrm{~h}$. C and $\mathrm{N}$ contents were measured on dried sediment $\left(60^{\circ} \mathrm{C}\right.$ for at least $\left.48 \mathrm{~h}\right)$ using a Carlo Erba Elemental Analyzer as described above. Exchangeable ammonium was determined by $\mathrm{KCl}$ extraction of sediments (Keeney \& Nelson 1982); ammonium concentrations were measured on a Lachat 8500 autoanalyzer.

Sediment grain size distributions were determined on samples collected in 2010 and were compared between Zostera marina-vegetated sediments and bare sediments. Two sediment cores were taken in each replicate plot down to a depth of $5 \mathrm{~cm}$ using a $60 \mathrm{~cm}^{3}$ syringe corer. Sediments were homogenized and a $10 \mathrm{ml}$ subsample was used for the grain size analysis. Organic matter (OM) was removed from the sediments by addition of a 50:50 bleach:water mixture; large organic material was removed by hand. After the sediment had completely settled and there was no evidence of OM, the excess water was decanted; the samples were then rinsed with deionized water and decanted 5 times to remove all bleach. A $5 \%$ sodium hexametaphosphate solution was then added to each sample as a dispersant, and the grain size analysis was then done on an LS 13320 Laser Diffraction Particle Size Analyzer (PSA; Beckman Coulter). Approximately 0.5 to $1.0 \mathrm{ml}$ of solution was added to the PSA. The PSA reports grain size distribution as \% volume for particle diameters of 0 to $500 \mu \mathrm{m}$. 


\section{Benthic chlorophyll}

Five surface sediment samples were collected in each plot to a depth of $1 \mathrm{~cm}$ with a $10 \mathrm{~cm}^{3}$ syringe corer for analysis of benthic chlorophyll. Collected samples were kept in the dark on ice until they were frozen at $-80^{\circ} \mathrm{C}$ immediately after returning to the laboratory. Samples were later thawed and extracted in a 45:45 methanol:acetone solution overnight in the freezer after a 1 min sonication. Benthic chlorophyll was determined spectrophotometrically using the equations of Lorenzen (1967).

\section{Statistics}

To test for differences between different-aged plots all replicates were averaged within a plot, and then an analysis of variance (ANOVA) was used, followed by a Tukey test to determine which specific age categories were different. Individual tests of means between bare and vegetated sediments were done using the Student's $t$-test, as noted. Differences were considered significant at $\mathrm{p}<0.05$.

\section{RESULTS}

\section{Eelgrass metrics}

The density of shoots was the metric that changed most significantly across the 9 yr age gradient. There was an initial $4 \mathrm{yr}$ lag in shoot density, with densities ranging from 14.2 to 105.4 shoots $\mathrm{m}^{-2}$. Shoot densities increased linearly in plots 6 to $9 \mathrm{yr}$ after seeding, from 249.3 to 616.7 shoots $\mathrm{m}^{-2}$, and were significantly different from plots 1 to $4 \mathrm{yr}$ after seeding (Fig. 1). The average canopy height was lower for the $1 \mathrm{yr}$ plants than for all other ages, although there were no significant differences in the canopy height for different-aged meadows due to the high variability in the $1 \mathrm{yr}$ meadows seeded and sampled in different years (averages 22.01 to $29.10 \mathrm{~cm}$ for $1 \mathrm{yr}$ meadows vs. 32.24 to $44.90 \mathrm{~cm}$ for 2 to $9 \mathrm{yr}$ meadows).

The average total biomass shoot ${ }^{-1}$ varied both within a given year and between meadows seeded in different years $\left(0.260\right.$ to $0.781 \mathrm{~g}$ dry weight shoot $\left.{ }^{-1}\right)$. However, there were no significant trends in biomass per shoot related to meadow age. The ratio of aboveto belowground biomass was also variable, and there were no significant differences between meadows of different ages. Variability within an age class was higher for the 1 to 4 yr meadows than for the 8 to $9 \mathrm{yr}$ meadows.

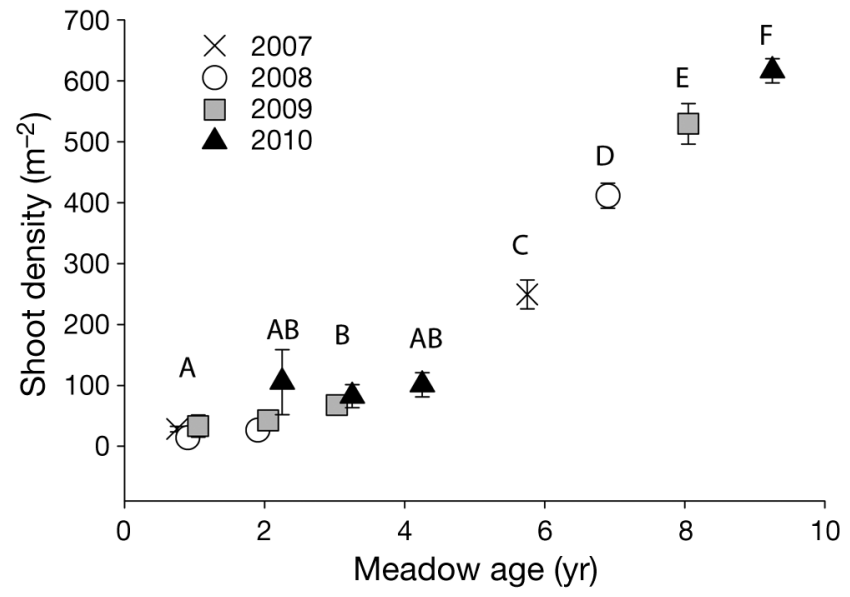

Fig. 1. Zostera marina. Shoot density in replicate 0.2 to 0.4 ha plots of eelgrass meadows restored by seeding in successive years, resulting in a chronosequence of sites from 1 to $9 \mathrm{yr}$ since seeding. Symbols denote the sampling year, and meadow age represents the time since seeding. Each data point represents 60 to 280 shoot counts; error bars are \pm SE. Different letters indicate significant differences between years. Shoot density increased slowly 1 to 4 yr after seeding and increased significantly each year in meadows 6 to 9 yr after seeding

Aboveground productivity, calculated as $\mathrm{cm}^{2}$ shoot $^{-1}$ $\mathrm{d}^{-1}$, during the peak summer periods varied considerably between meadows of different ages and between years when measurements were done, with no trends in individual shoot productivity over time since seeding (Fig. 2a). The higher productivity in the $7 \mathrm{yr}$ old meadow compared to the $8 \mathrm{yr}$ old meadow was likely related to lower temperatures in 2009 that caused lower shoot-specific productivity that year. Aerial rates of aboveground productivity $\left(\mathrm{cm}^{2} \mathrm{~m}^{-2}\right.$ $\mathrm{d}^{-1}$ ) increased with meadow age (Fig. $2 b, \mathrm{p}<0.0001$ ) and showed a trend similar to the eelgrass density, with an initial lag in productivity in the first few years after seeding. Productivity was not significantly higher until the meadows were 7 to 8 yr old.

\section{Sediment metrics}

Sediment OM varied significantly with time since seeding (Fig. 3a, p = 0.001). Initially, for meadows 1 to $2 \mathrm{yr}$ after seeding, there were no differences between the sediment $\mathrm{OM}$ in the meadows and the nearby bare sediments. There was an increasing trend in \%OM in meadows 4 and $7 \mathrm{yr}$ after seeding, and the OM was significantly higher in meadows $9 \mathrm{yr}$ after seeding. The accumulation of $\mathrm{OM}$ in eelgrass-vegetated sediments resulted in a doubling of $\mathrm{OM}$ in eelgrass meadows compared to 


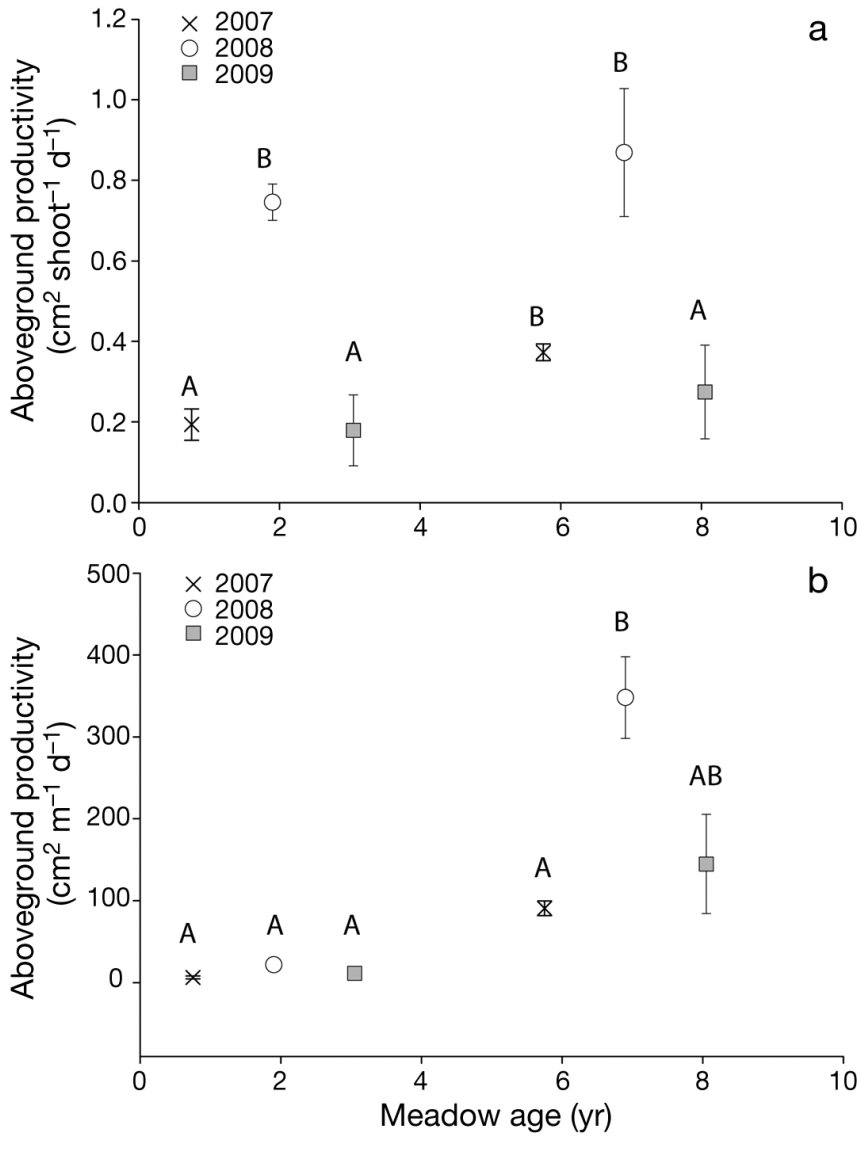

Fig. 2. Zostera marina. Rates of aboveground productivity in restored meadows as a function of time since seeding. (a) Productivity rates per shoot were variable from year to year and did not change significantly over time, whereas (b) areal productivity tracked patterns of shoot density. After $9 \mathrm{yr}$, meadows had 20 times higher rates of aerial productivity than 1 to 3 yr meadows. Error bars are $\pm S E$; different letters indicate significant differences between years

nearby bare sediments after $9 \mathrm{yr}$ (mean \pm SE: 2.35 \pm 0.13 vs. $1.39 \pm 0.22$ )

Exchangeable ammonium concentrations in sediments showed a similar significant trend of increasing concentrations with time since seeding (Fig. 3b, $\mathrm{p}<0.0001$ ). Meadows 1 to $2 \mathrm{yr}$ since seeding had exchangeable $\mathrm{NH}_{4}{ }^{+}$concentrations similar to those of nearby bare sediments, and there was a trend of increasing concentrations in $4 \mathrm{yr}$ meadows. Nine years after seeding, exchangeable $\mathrm{NH}_{4}{ }^{+}$concentrations had doubled in Zostera marina meadows compared to bare sediments.

There were no significant trends evident in either $\% \mathrm{C}$ or $\% \mathrm{~N}$ in sediments as Zostera marina meadows developed over time due to high variability both within and between age classes. C concentrations ranged from 0.23 to $0.47 \% \mathrm{C}$. N concentrations were always low, near the detection limit, and averages never exceeded $0.05 \% \mathrm{~N}$. However, both the average $\% \mathrm{C}$ and $\% \mathrm{~N}$ contents in the sediments of the 9 yr meadows were higher than nearby bare sediments $(\mathrm{C}: 0.467 \pm 0.021[$ mean $\% \pm 1 \mathrm{SE}]$ vs. $0.227 \pm$ $0.040, \mathrm{p}<0.004, \mathrm{~N}: 0.027 \pm 0.002$ vs. $0.008 \pm 0.003$, $\mathrm{p}<0.0001$, Student's $t$-test).

Sediment grain size distribution changed significantly over time since seeding, with fining of the sediment as meadows developed. This is evident in the PSA results, which showed a consistent decrease in the \% volume of sediment between 175 and $100 \mu \mathrm{m}$ diameter comparing bare sediments with sediments from meadows 2, 3, 4, and 9 yr since seeding, and an increase in the \% volume of sediment between 0 and $60 \mu \mathrm{m}$ diameter (Fig. 4a). Most of the sediment below $63 \mu \mathrm{m}$ was coarse silt; only $<0.5 \%$ of the total sedi-
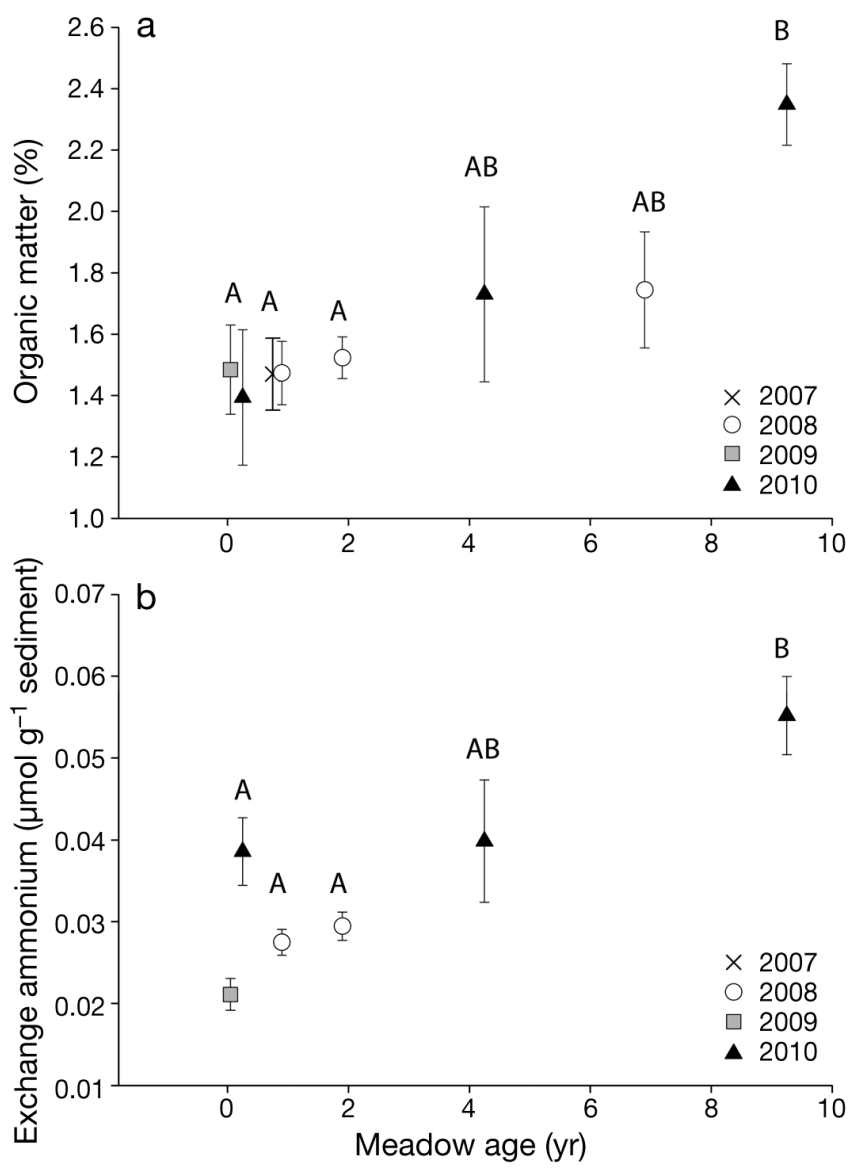

Fig. 3. (a) Sediment organic matter and (b) exchangeable ammonium concentrations in vegetated sediments in restored Zostera marina meadows as a function of time since seeding. Nearby bare, unvegetated sediments are represented as ' 0 ' age. Error bars are $\pm \mathrm{SE}$; different letters indicate significant differences between years. Nine years after seeding, sediment organic matter and exchangeable ammonium concentrations in $Z$. marina-vegetated sediments had doubled compared to bare sediments 

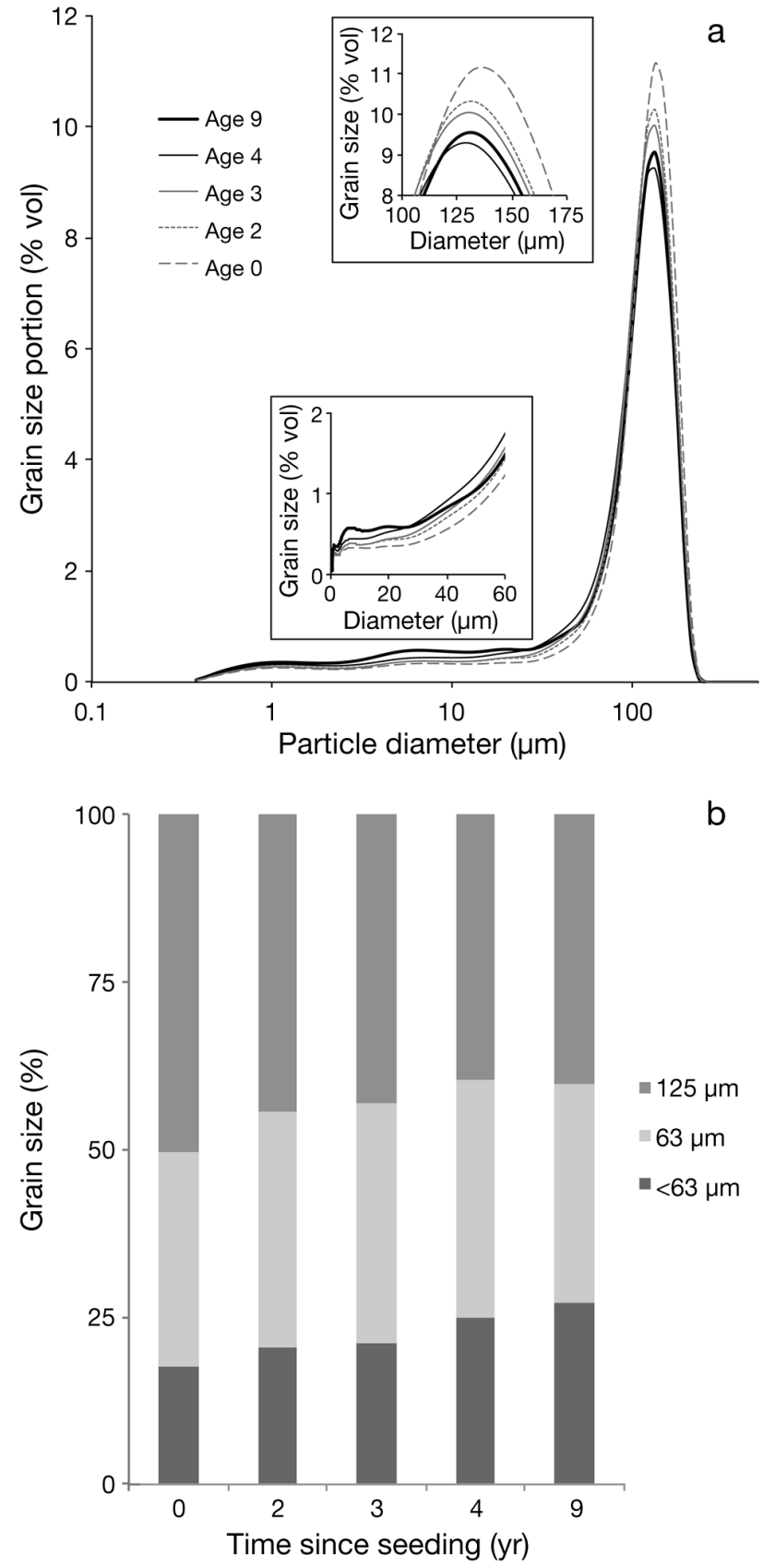

Fig. 4. (a) Grain size distributions in Zostera marina sediments. Small graphs show decrease in the \% volume of sediment between 175 and $100 \mu \mathrm{m}$ diameter comparing bare sediments with sediments from meadows 2, 3, 4, and $9 \mathrm{yr}$ since seeding, and an increase in the \% volume of sediment between 0 and $60 \mu \mathrm{m}$ diameter. (b) Pooled grain size data for the grain size categories: sand/clay $(<63 \mu \mathrm{m})$, very fine sand (63 to $125 \mu \mathrm{m})$, fine sand (>125 $\mu \mathrm{m})$. There was no sediment coarser than $250 \mu \mathrm{m}$

ment volume was $<31 \mu \mathrm{m}$ (clay to medium silt). The data from the PSA can also be binned to show the relative percent of the sediment volume in different size categories (Fig. 4b). Sediments from all sites were in the fine sand or smaller size classes $(<250 \mu \mathrm{m})$. Fig. $4 \mathrm{~b}$ shows the consistent increase in the proportion of the sediment of grain size below $<63 \mu \mathrm{m}$ (very fine sand and silt) during meadow development and a related decline in the proportion of the sediment of grain size $>125 \mu \mathrm{m}$ (fine sand). There was no sediment in the medium and coarse sand size classes $(>250 \mu \mathrm{m})$.

\section{Benthic chlorophyll}

There was no significant trend in benthic chlorophyll concentrations with time during meadow development, and concentrations in the Zostera marina meadows were similar to those in adjacent bare sediments. Concentrations ranged from 11.9 to $16.9 \mathrm{mg}$ $\mathrm{m}^{-2}$ in the bare sediments and 12.0 to $26.3 \mathrm{mg} \mathrm{m}^{-2}$ in the eelgrass-vegetated sediments.

\section{Depth distribution}

Seeds germinated in all plots along the depth gradient (0.9 to $1.6 \mathrm{~m} \mathrm{MSL}$ ); survival rates of Zostera marina shoots over time give an indication of the maximum depth limit for $Z$. marina at this site. After $4 \mathrm{yr}$, for plots seeded in 2006, no shoots survived at depths of $1.6 \mathrm{~m}$ MSL or greater (Fig. 5a). In addition, plots between 1.5 and $1.58 \mathrm{~m}$ MSL all showed a decrease in density, while density increased from 0 to $1750 \%$ in plots located at 0.9 to $1.5 \mathrm{~m}$ MSL depth (Fig. 5b). Taken together, these results suggest a threshold for survival related to light availability at 1.5 to $1.6 \mathrm{~m}$ MSL.

\section{DISCUSSION}

\section{Habitat suitability}

Habitat degradation is often a challenge for successful restoration, since in most regions the decline in seagrass has been attributed to multiple stressors, including eutrophication, sedimentation, and toxicity (Orth et al. 2006a, van der Heide et al. 2007). This is not the case in the Virginia coastal bays; recent work points to seed limitation rather than poor habitat quality as the limiting factor for recolonization and expansion of Zostera marina in the bays (Orth et al. 2012). The impressive areal expansion of the eelgrass meadows in these coastal bays (Orth et al. 2012) and the significant increase in eelgrass density described 


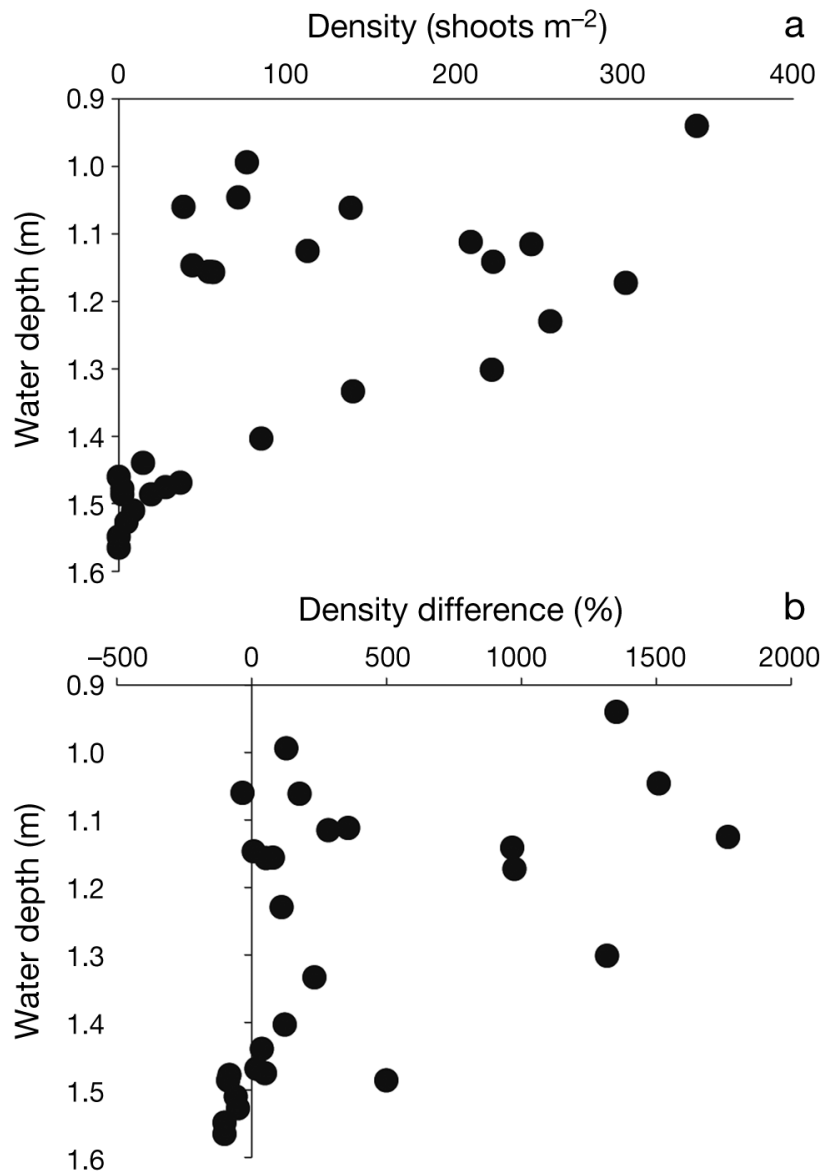

Fig. 5. Zostera marina. (a) Shoot density as a function of water depth at mean sea level, and (b) changes in shoot density for plots seeded in 2006 after 4 yr. Negative values represent a loss of shoots between 2007 and 2010

in the present study (up to $1750 \%$ in $4 \mathrm{yr}$ ) indicate that conditions are conducive to rapid meadow development. Nutrient loading to the coastal bays is low (2.1 $\mathrm{g} \mathrm{N} \mathrm{m}^{-2} \mathrm{yr}^{-1}$; Cole 2011), and is considerably lower than most other coastal bay systems (McGlathery et al. 2007). This is due to the low population density $\left(<30\right.$ people $\mathrm{km}^{-2}$ ) in the rural watersheds, the small ratio of watershed area to bay area, and the regional land use. The watersheds are dominated by forest and crop agriculture (corn, soybean, tomato); poultry farms do not contribute significantly to $\mathrm{N}$ loading as they do to other coastal bay systems in the mid-Atlantic (Stanhope et al. 2009, Cole 2011, Giordano et al. 2011).

Long-term data from the VCR LTER water quality monitoring program from 1992 to the present indicate that water quality parameters typically used to assess habitat suitability for Zostera marina have remained high and show no trends of decline over a nearly $20 \mathrm{yr}$ period (www1.vcrlter.virginia.edu/ home1/?q=data_wq). Average annual concentrations of chlorophyll a (1 to $6 \mu \mathrm{g}^{-1}$ ), dissolved inorganic $\mathrm{N}$ (1 to $7 \mu \mathrm{M})$, and dissolved inorganic phosphorus ( 0.3 to $1.3 \mu \mathrm{M})$ from monthly mainland-inlet transects across the bays are well within the range that can support growth of $Z$. marina in shallow shoals ( $<2 \mathrm{~m}$ at mean low water [MLW]; Dennison et al. 1993, Moore et al. 1996, Greve \& Krause-Jensen 2005). Previous work has shown that wind-driven sediment suspension is the dominant factor influencing light availability in these coastal bays, and accounts for periodic spikes in total suspended solid concentrations (Lawson et al. 2007). Despite this variability, Lawson et al. (2007) showed that $>60 \%$ of 1 of the coastal bays (Hog Island Bay) was suitable for seagrass growth based on light availability.

Sediment characteristics and local hydrodynamics in the Virginia coastal bays are also conducive to Zostera marina growth. The sediments are low in OM $(<2.5 \%)$ and are well below the average organic content suggested to generally limit seagrass growth (5\%, Barko \& Smart 1983, Koch 2001), although some Z. marina sediments have organic content as high as $16 \%$ (Koch 2001). Highly organic sediments typically have high concentrations of sulfides and ammonium, and low oxygen levels associated with decomposition, that may limit plant growth unless plants oxygenate the rhizosphere sufficiently to counteract the negative effects (Goodman et al. 1995, Lee \& Dunton 2000). Grain size also influences the accumulation of sulfides and ammonium and the depletion of oxygen in sediments (Holmer \& Nielsen 1997, Franke et al. 2006) because permeable sediments facilitate the exchange of overlying water column with porewater, which oxygenates the sediments (Huettel et al. 2003, Precht \& Huettel 2003). The bare sediments we studied had $\sim 80 \%$ sand, and after 9 yr the eelgrass-vegetated sediments had $\sim 75 \%$ sand, both well within the range of sand content found in healthy seagrass meadows (Koch 2001). Current and wave conditions were also sufficient to induce porewater exchange (Table 1; Hansen \& Reidenbach 2012).

\section{Recovery trajectories}

We expected to observe an initial lag phase after seeding before rapid meadow development occurred based on the reproductive phenology of Zostera marina in this region. Seedlings typically flower and produce seeds in their second year and thereafter, and those seeds that germinate and survive then again produce seeds after 2 yr. Our data clearly show 
this initial 4 yr lag in newly seeded meadows and a linear increase in shoot density in meadows 6 to $9 \mathrm{yr}$ since seeding. This pattern is analogous to the trends in recovering $Z$. marina meadows observed on larger spatial scales in Chincoteague Bay and Chesapeake Bay, where there was an initial lag of several years before meadow expansion increased rapidly, and is likely a general pattern for this region (Orth et al. 2010). The other plant and sediment parameters that changed over the 9 yr period, including areal $Z$. marina productivity and sediment organic and $\mathrm{NH}_{4}^{+}$ concentrations, also showed the same lag response in recovery, as these changes were strongly influenced by shoot density.

The recovery trajectory in the Virginia coastal bays is slower than that observed for Zostera marina meadows restored by transplanting in other regions. Evans \& Short (2005) showed that functional equivalence (with reference to natural meadows) of habitat structure based on shoot density, canopy height, and leaf area index was achieved after $3 \mathrm{yr}$, which is the typical time frame for monitoring programs (Evans $\&$ Short 2005). Other studies of restoration by transplanting have also shown similarly fast recovery of habitat structure and specific faunal communities (Fonseca et al. 1996a,b, Leschen et al. 2010), but Bell et al. (2008) found that percent cover of transplanted Halodule wrightii took more than 3 yr to reach $100 \%$ coverage equivalent to reference areas. Though perhaps slower to recover, an obvious advantage of the seeding technique we used is the large area that can be restored ( $>1700$ ha in this study after $9 \mathrm{yr}$; Orth et al. 2012). Specific recovery rates for seed-based restoration will likely depend both on the seed density used and the landscape context (e.g. proximity to adjacent meadows). The high rates of areal expansion of the eelgrass meadows in the Virginia coastal bays suggest that disturbance was not a significant factor limiting the success of restoration, as has been shown in other systems (Fonseca 2011, Valdemarsen et al. 2011).

Assessing the time to achieve functional equivalence of restored areas ideally involves reference sites that are of similar scale, located in similar conditions, and within close proximity (Addy 1947, Palmer et al. 1997, Craft et al. 2003, Simenstad et al. 2006, Bell et al. 2008, Fonseca 2011). These requirements were not possible to find for the restored Zostera marina meadows in the Virginia coastal bays; we initially followed Z. marina meadows in Chesapeake Bay and in southern-most coastal bay near the mouth of Chesapeake Bay. We eventually abandoned these as reference sites, as they were exposed to different environmental conditions than our restored sites (e.g. nutrients, hydrodynamics). Instead we use the trajectories to show the development of ecological function (or structural proxies for function) over time with the expectation that these characteristics will reach an asymptote, reflecting some long-term persistence, with natural fluctuations related to environmental variability or disturbance. These kinds of long-term studies are not common in seagrass meadows, and have been done in salt marshes on a 5 to $25 \mathrm{yr}$ time frame (Zedler 1996, Tyler \& Zieman 1999, Craft et al. 2002, 2003, Evans \& Short 2005). After 9 yr in the Virginia coastal bays, none of the eelgrass or sediment parameters we monitored have reached an asymptote, indicating that a decade or more is required to restore key functions in restored $Z$. marina meadows by seeding, even in a region with high habitat suitability. It is possible that low $\mathrm{N}$ concentrations in the Virginia coastal bays limit the rate of seagrass meadow development, as has been shown for restored marshes (Zedler 1996).

\section{Ecosystem services}

In this study we focused on 3 ecosystem services (functions) that eelgrass habitats provide: primary productivity, $\mathrm{C}$ and $\mathrm{N}$ sequestration, and sediment deposition. The conceptual diagram in Fig. 6 summarizes the changes we observed. We found that shoot density was the primary driver of areal rates of primary productivity, as there were no differences in productivity rates per shoot. As the meadows developed over time, productivity increased nearly 20fold, from an average of $13.2 \mathrm{~cm}^{2} \mathrm{~m}^{-2} \mathrm{~d}^{-1}$ in the first $3 \mathrm{yr}$ after seeding to $246.5 \mathrm{~cm}^{2} \mathrm{~m}^{-2} \mathrm{~d}^{-1}$ in 7 to $8 \mathrm{yr}$ old meadows. This latter rate accounts for significant year-to-year variation related to temperature, and is comparable to rates reported for mature $Z$. marina meadows (Dennison \& Alberte 1982). There were no differences in biomass per shoot, and areal biomass tracked changes in density, which agrees with the literature review of Olesen \& Sand-Jensen (1994), who showed that the maximum summertime leaf biomass of different populations of $Z$. marina did not vary with density. They suggested that self-thinning was not an important phenomenon in natural $Z$. marina meadows, presumably because the period of high leaf biomass was too short for negative feedbacks to occur. The densities in our meadows may not have approached the point where shoots would be expected to undergo density-dependent growth due to reduced light availability. 


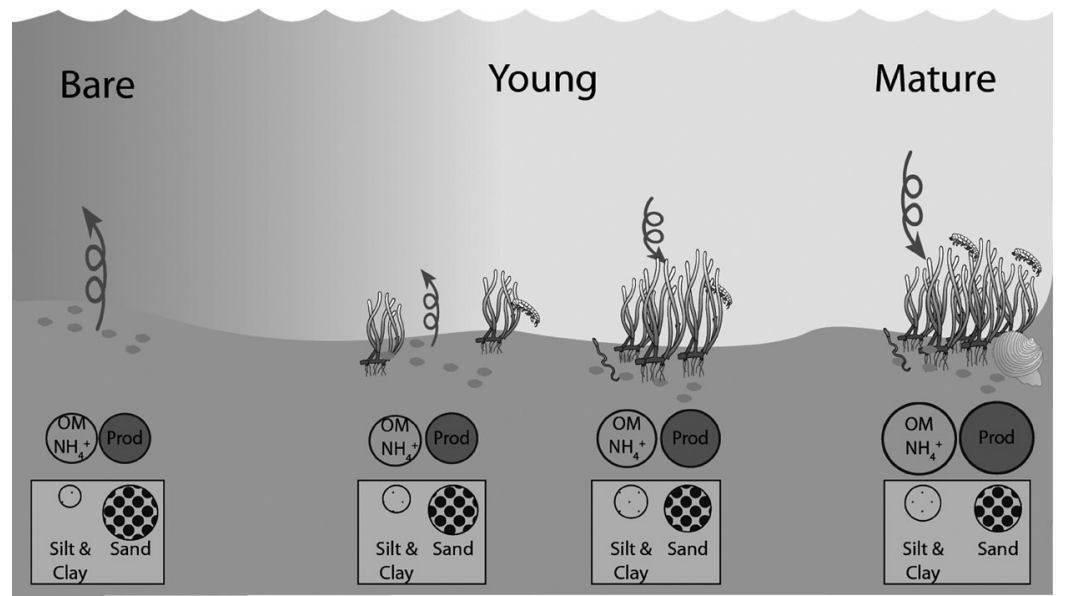

Fig. 6. Zostera marina. Conceptual diagram of the measured changes in structural and functional characteristics over time of restored meadows in the Virginia, USA, coastal bays. Arrows represent sediment suspension or deposition and show that sediment stability increases with meadow development. The relative proportions of sand and silt fractions change with meadow development (indicated by size of circles), with a fining of the sediments over time. The size of the circles for organic matter (OM) and $\mathrm{NH}_{4}{ }^{+}$concentrations indicates that both pools increase as meadows develop over time. The same is true for rates of productivity (Prod)

$\mathrm{C}$ and nutrient sequestration is an important, and relatively understudied, ecosystem service of seagrass meadows and other productive coastal habitats (Keith et al. 2009, Duarte et al. 2010, Kennedy et al. 2010, Donato et al. 2011). We calculated differences in the $\mathrm{C}$ and $\mathrm{N}$ concentrations in unvegetated sediments and 9 yr Zostera marina meadows as a firstorder estimate of the accumulation of $\mathrm{C}$ and $\mathrm{N}$ standing stocks in $Z$. marina meadows, assuming that the bare sediment represented the initial condition (Fig. 7). Sediment standing stocks were determined from measures of $\% \mathrm{C}, \% \mathrm{~N}$, and bulk density in surface sediments to a depth of $5 \mathrm{~cm}$. Vegetated sediments stored more than twice as much $\mathrm{C}(278.9$ versus $138.7 \mathrm{~g} \mathrm{~m}^{-2}$ ) and 3 times more $\mathrm{N}$ (16.2 vs. $5.1 \mathrm{~g}$ $\mathrm{m}^{-2}$ ) than unvegetated sediments. Sediments comprised a larger pool of stored $\mathrm{C}$ and $\mathrm{N}$ than vegetation, similar to what is observed for salt marsh ecosystems (Craft et al. 1988, Morris et al. 2002, Chmura et al. 2003). Including the $\mathrm{C}$ temporarily stored in $Z$. marina biomass during this period of maximum production, eelgrass habitats stored 3 times the $\mathrm{C}$ and over 4 times the $\mathrm{N}$ compared to unvegetated sediments. We are continuing this work to determine annual accumulation rates of $\mathrm{C}$ in sediments, but these initial estimates clearly demonstrate the potential role of seagrass restoration in increasing $\mathrm{C}$ and $\mathrm{N}$ sequestration in shallow coastal ecosystems (Irving et al. 2011).
The presence of dense seagrass meadows can improve local water quality by attenuating wave energy and near-bed currents, increasing particle deposition, and reducing sediment suspension (Ward et al. 1984, Fonseca \& Fisher 1986, Gacia et al. 2002, Hendriks et al. 2008, Gruber \& Kemp 2010). We show significant fining of the sediments in eelgrass meadows as shoot densities increased over time, indicating that finer (clay/silt) particles were being deposited and retained within the meadows. These results are consistent with a study conducted concurrently showing that the restored Zostera marina meadows reduced near-bottom current velocities by 70 to $90 \%$ and wave heights by 45 to $70 \%$ compared to nearby unvegetated sediments and that expansion of the meadows has changed the 
seafloor from being an erosional to a depositional environment (Hansen \& Reidenbach 2012). In addition, water clarity measurably improved in the South Bay meadows as Z. marina became denser from 2002 to 2010 (Orth et al. 2012). Sediment OM and exchangeable $\mathrm{NH}_{4}{ }^{+}$also were twice as high in $9 \mathrm{yr}$ meadows compared to 1 to 3 yr meadows, indicating that the restored eelgrass meadows are important repositories of $\mathrm{OM}$, some of which accumulates as discussed above, and some of which is decomposed in situ. Given the consistently low water column chlorophyll concentrations, it is likely that either resuspended benthic microalgae from nearby unvegetated areas or eelgrass detritus are the largest contributors to the OM accumulation in these eelgrass meadows. This agrees with what Gacia et al. (2002) found for a Posidonia oceanica meadow where benthic diatoms and filamentous algae dominated the organic particle flux to seagrass sediments, except during times of phytoplankton blooms.

\section{Depth limits and future trajectories}

The positive feedback of Zostera marina on sediment stability and light availability is strong enough to induce depth-dependent bistable dynamics in these shallow coastal bays, with the 2 states being a $Z$. marina meadow and bare, unvegetated sediments (Carr et al. 2012). Our experimental data show that restored eelgrass did not survive at $1.6 \mathrm{~m} \mathrm{MSL}$, and that densities declined at water depths below $1.5 \mathrm{~m}$ MSL. These field results match remarkably well with the model results of Carr et al. (2012) that identify 1.6 m MSL as the 'tipping point,' or maximum depth that can support expanding seagrass meadows under current conditions in this system. The model indicates the bistable range to be 1.6 to $1.8 \mathrm{~m} \mathrm{MSL}$, where either $Z$. marina meadows or the bare sediment state could exist, depending on initial densities and environmental conditions (e.g. temperature). Modeling of future climate change scenarios suggests that meadows in the bistable range have limited resilience and that increases in water column temperatures would push a meadow past a critical bifurcation point to a bare sediment state from which recovery would not be possible (Carr et al. 2012). In effect, this would decrease the depth limit of $Z$. marina and reduce the suitable area for eelgrass expansion in the coastal bays. Changes in temperature and/or wave exposure associated with future climate change may also influence the minimum depth limit of $Z$. marina in this system, pushing the mead- ows to deeper waters and 'squeezing' the suitable habitat to a narrower depth range. By continuing field monitoring of restored meadows, and incorporating mechanistic studies of habitat effects on productivity and minimum light requirements of $Z$. marina and modeling, we can achieve a better understanding of the potential for continued recovery in the region.

Acknowledgements. We are grateful for the logistical support provided by the research staff at the University of Virginia's Anheuser-Busch Coastal Research Center. Funding for this study was provided by National Science Foundation grant DEB-0621014 to the Virginia Coast Reserve LTER project, the Department of Environmental Sciences at the University of Virginia, the Coastal Programs of the Virginia Department of Environmental Quality (funded by the Coastal Zone Management Act of 1972, as amended, administered by NOAA's Office of Ocean and Coastal Resource Management), the Virginia Recreational Fishing License Fund, and the Keith Campbell Foundation for the Environment. This is contribution no. 3217 from Virginia Institute of Marine Science.

\section{LITERATURE CITED}

Addy CE (1947) Eelgrass planting guide. MD Conserv 24: $16-17$

Anderson IC, McGlathery KJ, Tyler AC (2003) Microbial mediation of 'reactive' nitrogen transformations in a temperate lagoon. Mar Ecol Prog Ser 246:73-84

Anderson IC, Stanhope JW, Hardison AK, McGlathery KJ (2010) Sources and fates of nitrogen in Virginia Coastal Bays. In: Kennish M, Paerl H (eds) Coastal lagoons: critical habitats of environmental change. CRC Press, Boca Raton, FL, p 43-72

Barko JW, Smart AM (1983) Effects of organic matter additions to sediment on the growth of aquatic plants. J Ecol 71:161-175

> Bell SS, Tewfik A, Hall MO, Fonseca MS (2008) Evaluation of seagrass planting and monitoring techniques: implications for assessing restoration success and habitat equivalency. Restor Ecol 16:407-416

> Carr J, D'Odorico P, McGlathery KJ, Wiberg PL (2010) Stability and bistability of seagrass ecosystems in shallow coastal lagoons: role of feedbacks with sediment resuspension and light attenuation. J Geophys Res 115: G03011 doi:10.1029/2009JG001103

> Carr JA, D'Odorico P, McGlathery KJ, Wiberg PL (2012) Modeling the effects of climate change on eelgrass stability and resilience: future scenarios and leading indicators of collapse. Mar Ecol Prog Ser 448:289-301

> Chen C, Beardsley RC, Cowles G (2006) An unstructured grid, finite-volume coastal ocean model (FVCOM) system. Oceanography 19:78-89

Chmura GL, Anisfield SC, Cahoon DR, Lynch JC (2003) Global carbon sequestration in tidal, saline wetland soils. Global Biogeochem Cycles 17:1111 doi:10.1029/2002GB 001917

Cole LW (2011) Inputs and fluxes of nitrogen in the Virginia coastal bays: effects of newly-restored seagrasses on the nitrogen cycle. PhD dissertation, University of Virginia, 
Charlottesville, VA

Craft C, Broome S, Seneca E (1988) Nitrogen, phosphorus, and organic carbon pools in natural and transplanted marsh soils. Estuaries 11:272-280

> Craft C, Broome SW, Campbell CL (2002) Fifteen years of vegetation and soil development following brackishwater marsh creation. Restor Ecol 10:248-258

> Craft C, Megonigal P, Broome S, Stevenson J and others (2003) The pace of ecosystem development of constructed Spartina alterniflora marshes. Ecol Appl 13: $1417-1432$

> Dennison WC, Alberte RS (1982) Photosynthetic responses of Zostera marina L. (eelgrass) to in situ manipulations of light intensity. Oecologia 55:137-144

Dennison WC, Orth RJ, Moore KA, Stevenson JC and others (1993) Assessing water quality with submersed aquatic vegetation. Bioscience 43:86-94

Donato DC, Kauffman JB, Murdiyarso D, Kunianto S, Stidham M, Kanninen M (2011) Mangroves among the most carbon-rich forests in the tropics. Nat Geosci 4: 293-297

> Duarte CM, Middelburg JJ, Caraco N (2005) Major role of marine vegetation on the oceanic carbon cycle. Biogeosciences 2:1-8

> Duarte CM, Marba N, Gacia E, Fourqurean JW, Beggins J, Barron C, Apostolaki ET (2010) Seagrass community metabolism: assessing the carbon sink capacity of seagrass meadows. Global Biogeochem Cycles 24:GB4032 doi:10.1029/2010GB003793

Duffy JE (2006) Biodiversity and the functioning of seagrass ecosystems. Mar Ecol Prog Ser 311:233-250

Elliott M, Burdon D, Hemingway KL, Apitz SE (2007) Estuarine, coastal and marine ecosystem restoration: confusing management and science - a revision of concepts. Est Coast Sci 74:349-366

Evans NT, Short FT (2005) Functional trajectory models for assessment of transplanted eelgrass, Zostera marina L., in the Great Bay Estuary, New Hampshire. Estuaries 28: 936-947

Folkard AM (2005) Hydrodynamics of model Posidonia oceanica patches in shallow water. Limnol Oceanogr 50: 1592-1600

> Fonseca MS (2011) Addy revisited: What has changed with seagrass restoration in 64 years? Ecol Restor 29:73-81

Fonseca MS, Fisher JS (1986) A comparison of canopy friction and sediment movement between four species of seagrass with reference to their ecology and restoration. Mar Ecol Prog Ser 29:15-22

Fonseca MS, Kenworthy WJ, Courtney FX (1996a) Development of planted seagrass beds in Tampa Bay, Florida, USA. I. Plant components. Mar Ecol Prog Ser 132:127-139

Fonseca MS, Meyer DL, Hall MO (1996b) Development of planted seagrass beds in Tampa Bay, Florida, USA. II. Faunal components. Mar Ecol Prog Ser 132:141-156

Fonseca MS, Kenworthy WJ, Thayer GW (1998) Guidelines for the conservation and restoration of seagrasses in the United States and adjacent waters. NOAA Coastal Ocean Program, Decision Analysis Series No. 12. National Oceanic and Atmospheric Association, Washington, DC

- Franke U, Polerecky L, Precht E, Huettel M (2006) Wave tank study of particulate organic matter degradation in permeable sediments. Limnol Oceanogr 51:1084-1096

Fugate DC, Friedrichs CT, Biligil A (2006) Estimation of residence time in a shallow back barrier lagoon, Hog
Island Bay, Virginia, USA. In: Spaulding M (ed) Proc 9th Int Conf Estuar Coastal Model. ASCE, Reston, VA, p 319-337

> Gacia E, Duarte CM, Middelburg JJ (2002) Carbon and nutrient deposition in a Mediterranean seagrass (Posidonia oceanica) meadow. Limnol Oceanogr 47:23-32

> Giordano JCP, Brush MJ, Anderson IA (2011) Quantifying annual nitrogen loads to Virginia's coastal lagoons: sources and water quality response. Estuar Coasts 34: 297-309

Goodman JL, Moore KA, Dennison WC (1995) Photosynthetic responses of eelgrass (Zostera marina L.) to light and sediment sulfide in a shallow barrier island lagoon. Aquat Bot 50:37-47

Greve TM, Krause-Jensen D (2005) Predictive modeling of eelgrass (Zostera marina) depth limits. Mar Biol 146: 849-858

Gruber RK, Kemp WM (2010) Feedback effects in a coastal canopy-forming submersed plant bed. Limnol Oceanogr 55:2285-2298

Hansen JCR, Reidenbach MA (2012) Wave and tidally driven flows in eelgrass beds and their effect on sediment suspension. Mar Ecol Prog Ser 448:271-287

Heck KL, Carruthers TJB, Duarte CM, Hughes AR, Kendrick G, Orth RJ, Williams SW (2008) Trophic transfers from seagrass meadows subsidize diverse marine and terrestrial consumers. Ecosystems 11:1198-1210

> Hendriks IE, Sintes T, Bouma TJ, Duarte CM (2008) Experimental assessment and modeling evaluation of the effects of seagrass Posidonia oceanica on flow and particle trapping. Mar Ecol Prog Ser 356:163-173

Holmer M, Nielsen SL (1997) Sediment sulfur dynamics related to biomass-density patterns in Zostera marina (eelgrass) beds. Mar Ecol Prog Ser 146:163-171

> Huettel M, Roy H, Precht E, Ehrenhauss S (2003) Hydrodynamical impact on biogeochemical processes in aquatic sediments. Hydrobiologia 494:231-236

> Irving AD, Connell SD, Russell BD (2011) Restoring coastal plants to improve global carbon storage: reaping what we sow. PLoS ONE 6:e18311

Keeney DR, Nelson DW (1982) Nitrogen-inorganic forms. In: Page AL, Miller RH (eds) Methods of soil analysis, 2nd edn. American Society of Agronomy: Soil Science Society of America, Madison, WI, p 643-693

> Keith H, Mackey B, Lindenmayer DB (2009) Re-evaluation of forest biomass carbon stocks and lessons from the world's most carbon-dense forests. Proc Natl Acad Sci USA 106:11635-11640

Kennedy H, Beggins J, Duarte CM, Fourqurean JW, Holmer M, Marbà N, Middelburg JJ (2010) Seagrass sediments as a global carbon sink: isotopic constraints. Global Biogeochem Cycles 24:GB4026 doi:10.1029/2010GB003848

> Koch EW (2001) Beyond light: physical, geological and geochemical parameters as possible submersed aquatic vegetation habitat requirements. Estuaries 24:1-17

Lawson SE, Wiberg PL, McGlathery KJ, Fugate DC (2007) Wind-driven sediment suspension controls light availability in a shallow coastal lagoon. Estuar Coasts 30: 102-112

- Lawson SE, McGlathery KJ, Wiberg PL (2012) Enhancement of sediment suspension and nutrient flux by benthic macrophytes at low biomass. Mar Ecol Prog Ser 448: $259-270$

Lee K, Dunton KH (2000) Diurnal changes in pore water sulfide concentrations in the seagrass Thalassia testudinum 
beds: the effects of seagrasses on sulfide dynamics. J Exp Mar Biol Ecol 255:201-214

Leschen AS, Ford KH, Evans NT (2010) Successful eelgrass (Zostera marina) restoration in a formerly eutrophic estuary (Boston Harbor) supports the use of a multifaceted watershed approach to mitigating eelgrass loss. Estuar Coasts 33:1340-1354

> Li W, Kim JH, Park JI, Lee KS (2010) Assessing establishment success of Zostera marina transplants through measurements of shoot morphology and growth. Estuar Coast Shelf Sci 88:377-384

> Lorenzen C (1967) Determination of chlorophyll and phaeopigments: spectrophotometric equations. Limnol Oceanogr 12:343-346

> McGlathery KJ, Anderson IC, Tyler AC (2001) Magnitude and variability of benthic and pelagic metabolism in a temperate coastal lagoon. Mar Ecol Prog Ser 216:1-15

> McGlathery KJ, Sundback K, Anderson IC (2007) Eutrophication in shallow coastal bays and lagoons: the role of plants in the coastal filter. Mar Ecol Prog Ser 348:1-18

Milne LJ, Milne MJ (1951) The eelgrass catastrophe. Sci Am 184:52-55

Moore KA, Orth RJ, Nowak JF (1993) Environmental regulation of seed germination in Zostera marina L. (eelgrass) in Chesapeake Bay: effects of light, oxygen and sediment burial. Aquat Bot 45:79-91

> Moore KA, Neckles HA, Orth RJ (1996) Zostera marina (eelgrass) growth and survival along a gradient of nutrients and turbidity in the lower Chesapeake Bay. Mar Ecol Prog Ser 142:247-259

> Morris JT, Sundareshwar PV, Nietch CT, Kjerfve B, Cahoon DR (2002) Responses of coastal wetlands to rising sea level. Ecology 83:2869-2877

Oertel G (2001) Hypsographic, hydro-hypsographic and hydrological analysis of coastal bay environments, Great Machipongo Bay. J Coast Res 17:775-783

Olesen B, Sand-Jensen K (1994) Biomass-density patterns in the temperate seagrass Zostera marina. Mar Ecol Prog Ser 109:283-291

Orth RJ, Carruthers TJB, Dennison WC, Duarte CM and others (2006a) A global crisis for seagrass ecosystems. Bioscience 56:987-996

Orth RJ, Luckenbach ML, Marion SR, Moore KA, Wilcox DJ (2006b) Seagrass recovery in the Delmarva Coastal Bays, USA. Aquat Bot 84:26-36

> Orth RJ, Marion SR, Moore KA, Wilcox DJ (2010) Eelgrass (Zostera marina L.) in the Chesapeake Bay region of the Mid-Altantic coast of the USA: challenges in conservation and restoration. Estuar Coasts 33:139-150

> Orth RJ, McGlathery KJ (2012) Eelgrass recovery in the coastal bays of the Virginia Coast Reserve, USA. Mar Ecol Prog Ser 448:173-176

> Orth RJ, Moore KA, Marion SR, Wilcox DJ, Parrish DB (2012) Seed addition facilitates eelgrass recovery in a coastal bay system. Mar Ecol Prog Ser 448:177-195

> Palmer MA, Ambrose RF, Poff NL (1997) Ecological theory

Submitted: July 5, 2011; Accepted: December 20, 2011 and community restoration ecology. Restor Ecol 5: 291-300

Precht E, Huettel M (2003) Advective pore-water exchange driven by surface gravity waves and its ecological implications. Limnol Oceanogr 48:1674-1684

Reynolds LK, Waycott M, McGlathery KJ, Orth RJ, Zieman JC (2012) Eelgrass restoration by seed maintains genetic diversity: case study from a coastal bay system. Mar Ecol Prog Ser 448:223-233

> Short FT, Davis RC, Kopp BS, Short CA, Burdick DM (2002) Site-selection model for optimal transplantation of eelgrass Zostera marina in the northeastern US. Mar Ecol Prog Ser 227:253-267

Short FT, Polidoro B, Livingstone SR, Carpenter KE and others (2011) Extinction risk assessment of the world's seagrass species. Biol Conserv 144:1961-1971

> Simenstad C, Reed D, Ford M (2006) When is restoration not? Incorporating landscape-scale processes to restore self-sustaining ecosystems in coastal wetland restoration. Ecol Eng 26:27-39

Stanhope JW, Anderson IC, Reay WC (2009) Base flow nutrient discharges from lower Delmarva Peninsula watersheds of Virginia, USA. J Environ Qual 38:2070-2083

Tyler AC, Zieman JC (1999) Patterns of development in the creekbank region of a barrier island Spartina alterniflora marsh. Mar Ecol Prog Ser 180:161-177

Tyler AC, McGlathery KJ, Anderson IC (2001) Macroalgal mediation of dissolved organic nitrogen fluxes in a temperate coastal lagoon. Estuar Coast Shelf Sci 53:155-168

> Tyler AC, McGlathery KJ, Anderson IC (2003) Benthic algae control sediment-water column fluxes of organic and inorganic nitrogen compounds in a temperate lagoon. Limnol Oceanogr 48:2125-2137

Valdemarsen T, Wendelboe K, Egelund JT, Kristensen E, Flindt MR (2011) Burial of seeds and seedlings by the lugworm Arenicola marina hampers eelgrass (Zostera marina) recovery. J Exp Mar Biol Ecol 410:45-52

> van der Heide T, van Nes EH, Geerling GW, Smolders AJP, Bouma TJ, van Katwijk MM (2007) Positive feedbacks in seagrass ecosystems: implications for success in conservation and restoration. Ecosystems 10:1311-1322

> van Katwijk MM, Bos AR, de Jonge VN, Hansse LSAM, Hermus DCR, de Jong DJ (2009) Guidelines for seagrass restoration: importance of habitat selection and donor population, spreading of risks, and ecosystem engineering effects. Mar Pollut Bull 58:179-188

Ward LG, Kemp WM, Boynton WR (1984) The influence of waves and seagrass communities on suspended particulates in an estuarine embayment. Mar Geol 59:85-103

> Waycott M, Duarte CM, Carruthers TJB, Orth RJ and others (2009) Accelerating loss of seagrasses across the globe threatens coastal ecosystems. Proc Natl Acad Sci USA 106:12377-12381

Zedler JB (1996) Coastal mitigation in southern California: the need for a regional restoration strategy. Ecol Appl 6: $84-93$

Proofs received from author(s): February 10, 2012 